\title{
PHENOLICS WITH LEISHMANICIDAL AND IMMUNOMODULATORY PROPERTIES
}

\section{COMPUESTOS FENÓLICOS CON PROPIEDADES LEISHMANICIDAS E INMUNOMODULADORAS}

Jeysson Sánchez-Suárez', Julián Pérez-Cordero², Ericsson Coy-Barrera³

\begin{abstract}
Leishmaniasis currently remains as a public health problem that it has become important, especially in developing countries, where the disease is endemic for most of them. Increased reports on therapeutic failures by the rise of resistant strains as well as the severity of the side effects known for current treatments have promoted an imperative searching for novel antileishmanial agents. Such exploration has established that, in addition to the parasiticide effect, an immunomodulatory action could significantly contribute in therapeutics against leishmaniasis. The crucial observation through findings on immunomodulatory compounds is the nonactivity against promastigotes but selective parasiticide effect against macrophage-internalized amastigotes. However, the published examples of this type of action are few but very interesting. Therefore, the present work summarizes some naturally-occurring phenolic-type compounds with antileishmanial activity whose effect has been suggested to be exerted through an immunomodulatory mechanism.
\end{abstract}

Keywords: Phenolics, Leishmania, immunomodulatory.

1. Programa Medicina, Facultad de Ciencias de la Salud, Universidad de Ciencias Aplicadas y Ambientales - UDCA, Bogotá - Colombia.

2. Departamento de Bioclínica, Facultad de Medicina, Universidad El Bosque, Bogotá - Colombia.

3. Laboratorio de Química Bioorgánica, Facultad de Ciencias Básicas y Aplicadas, Universidad Militar Nueva Granada, CajicáColombia.E-mail: inqubio@unimilitar.edu.co 


\section{RESUMEN}

La leishmanioisis permanece actualmente como un problema de salud pública que ha cobrado gran relevancia, sobre todo en países en vía de desarrollo, en cuya mayoría, la enfermedad es endémica. El incremento de reportes de fallo terapéutico por la aparición de cepas resistentes así como la severidad de los efectos adversos conocidos para los tratamientos actuales, han hecho imperativa la búsqueda de nuevos agentes antileishmaniales. En ésta búsqueda se ha establecido que, adicional al efecto parasitocida, un potencial inmunomodulador podría contribuir significativamente en la terapéutica contra leishmaniosis. Una observación importante, a través de los resultados relacionados con compuestos que poseen efecto inmunomodulador, es la actividad parasitocida selectiva contra la forma amastigote internalizada en macrófagos, ya que la acción contra promastigotes es prácticamente nula. No obstante, en la literatura se encuentran muy pocos ejemplos de este tipo de acciones aunque son muy interesantes. Por lo tanto, el presente trabajo muestra una revisión acerca de compuestos fenólicos con potencial antileishmanial, cuyo mecanismo sugerido es la inmunomodulación.

Palabras clave: Compuestos fenólicos, Leishmania, Inmunomodulación

\section{INTRODUCTION}

Since 1988, the term leishmaniosis, instead leishmaniasis, is the name kept by the World Association for the Advancement of Veterinary Parasitology (WAAVP) and the World Federation of Parasitologists, according to the "Standardized Nomenclature of Animal Parasitic Diseases" (SNOAPAD) (Velez, 1995) in order to refer to the disease caused by parasites of the genus Leishmania. However, the term of leishmaniasis is used more frequently than leishmaniosis (Kassai, 2006).

Leishmaniosis is defined as a group of diseases with high rates of morbidity and mortality in most developing countries (WHO, 2006). The disease is caused by various species of Leishmania (Kinetoplastidae order). 15 species of Leishmania are well known for causing the illness in humans, but 13 of them exhibit zoonotic nature (Myler and Fasel, 2008). Leishmania spp. is transmitted by ca. 30 species of sandflies of the genus Lutzomyia in the New World, and the genus Phlebotomus in the Old World. In Colombia, L. panamensis and L. braziliensis are the etiological agents associated with more widely distributed leishmaniosis (Saravia et al., 2002). However, a recent study has shown an increasing in the prevalence and distribution of L. guyanensis in Colombia, reporting it as the etiologic agent in $94.6 \%$ cases in three zones in Tolima (Rodriguez-Barraquer et al., 2008), whose incidence until that report was confined to the Orinoco and Amazon basin regions (Saravia et al., 1998).

\section{EPIDEMIOLOGY AND CLINICAL ASPECTS OF LEISHMANIOSIS}

Depending on the parasite species involved into the infection and some host factors (taking into account the symptoms exhibited by individuals after infection) leishmaniosis can be classified in three clinical syndromes: cutaneous leishmaniosis (CL), mucocutaneous 
leishmaniosis (MCL) and visceral leishmaniosis ( $\mathrm{VL})$. The last one is the most critical form of the disease, which can be lethal if it is untreated (Sharma and Singh, 2009).

Leishmaniosis is contemplated to be prevalent in 88 countries, but 32 of them really consider it as endemic. This condition has led to an underestimation of reality as well as a significant public health problem (Assimina et al., 2008). This disease affects more than $12 \mathrm{mi}$ Ilion people worldwide. It is considered that 350 million people are at risk of acquiring it, and each year worldwide are reported ca. 2 million new infections $\mathrm{WHO}$, 2009). In Colombia, the disease is manifested as endemic. In 1994, 1079 municipalities were found to have leishmaniosis reports, predicting a change in the incidence rate within 2.00-6.66 range per 100,000 subjects in the rural population (King et al., 2004). Between 2003 and 2004, 10,000 cases/year were reported, and in 2005 the number of cases was close to 18,000 (Robledo et al., 2006). During 2009, 15,474 cases were reported, $98.9 \%$ of them were found to be cutaneous leishmaniosis (Gutierrez-Dueñas, 2010). In 2010, the scenario did not change and the System of Public Health Surveillance (SIVIGILA, Colombia) reported 14,851 cases of leishmaniosis (98.7\% cases of cutaneous leishmaniosis) (Gutierrez-Dueñas, 2011), while during 2011, 9241 cases were recorded $(98.07 \%$ of these were found to exhibit cutaneous type) (Gómez-Romero, 2012). However, it is important to note that these statistics do not consider the underreporting of the disease. For Colombia, 75\% cases of CL were reported in Antioquia, Caquetá, Guaviare, Meta, Nariño, Santander, and Tolima Departments. Meanwhile, cases of VL were found to be concentrated in Bolivar, Cordoba, Sucre, and Tolima (PAHO, 2007).

\section{TREATMENT, SIDE EFFECTS AND DRUG RESISTANCE}

Pentavalent antimonial salts are the first-line treatments, which should be either intramuscularly or intravenously administered during an average of 4 weeks, despite their reported high toxicity (Rodrigues et al., 1999). The cost of such treatment might be US\$30 (generic sodium stibogluconate), US\$120 (meglumine antimoniate, Glucantime $\AA$ ), and US\$ 150 (sodium stibogluconate, Pentostam $®$ ) (Reithinger and Coleman, 2007). In clinical cases where therapeutic failure is reported, the second-line drugs for the control of leishmaniosis are highly toxic and their costs range from US\$ 60 (Amphotericin B) and US\$ 70 (Pentamidine, Pentacarinat $\AA$ ). Although the liposomal amphotericin B has not been associated with serious adverse effects, its high cost does not favor the accessing for the most affected population (it can exceed US\$1500 per treatment) (WHO, 2006).

In addition to the costs and adverse effectsderived drawbacks, the problematic is increased by complications such as long distances for accessing health centers and the transportation difficulties, among other problems which have promoted the occurrence of resistant strains towards treatment (Pérez-Victoria et al., 2006; Rojas et al., 2006; Ribeiro-Gomes et al., 2004). This resistance acquisition (or susceptibility loss) by the parasite, along with the lack of therapeutic options, is reflected in dosage and therapy duration increases (Croft et al., 2006), as so in the incidence of the known adverse effects for these formulations, even until death (Monzote, 2009). The resistance of antileishmanial chemotherapy has been reported in Southern Europe, Iran, Northeast India and South America (Rojas et al., 2006; Mohapatra, 2014).

All above-mentioned facts, joined to the lack of a vaccine, render a requirement based on the imperative searching for new chemotherapeutic alternatives. Understanding the pathogenesis of leishmaniosis, the development and implementation of immune based treatments could offer better opportunities for a successful therapy. Because of that, naturallyoccurring compounds possessing leishmanicidal 


\section{The role of the immunesystem in the development ofleishmaniasis has been well-established to be crucial. In this context, some individuals are naturally able for controlling the infection. Thus, following the experimental evidence is exposed remarking the role of the immune system response in the pathology control.}

and immunomodulatory properties would be preferable ones (Singh and Sundar, 2014). There are many considerations on the important role that the regulatory factors from host immune status have on natural resistance or susceptibility against infection (Faleiro et al., 2014).

\section{IMMUNOMODULATORY ROLES IN LEISHMANIOSIS CONTROL}

The role of the immune system in the development of leishmaniasis has been well-established to be crucial. In this context, some individuals are naturally able for controlling the infection. Thus, following the experimental evidence is exposed remarking the role of the immune system response in the pathology control.

In LC-infected individuals [who respond favorably to the treatment with sodium stibogluconate (Sb)] has been reported a decrease in the expression levels of IL-13 (cytokine of a Th2 profile) in contrast to that observed in individuals who fail treatment, and even, it has been seen that these individuals are characterized by the production of IL10 in macrophages and T cells (Maurer-Cecchini et al., 2009). This result is consistent with the inhibitory effects of IL-10 on IL-12 (Aste-Amezaga et al., 1998) and IFN- $Y$ (D'Andrea, 1993).
In "knock-out" C57BL/6 mice has shown a marked reduction in the effectiveness of Sb for the IFN- $\mathrm{Y}$ gene. In addition, LV-infected patients treated with $\mathrm{Sb}$ together with recombinant IFN- $\mathrm{y}$ replied to the treatment faster than those treated only with $\mathrm{Sb}$ (Sundar et al., 1995). A study involving L. peruvianainfected patients that exhibited no response towards treatment with meglumine antimoniate indicates that when patients were treated with this pentavalent antimoniate therapy combined with imiquimod (an immunomodulatory drug), 90\% patients resolved the infection after 6 months (Arevalo et al., 2001). The foregoing evidence suggests that immunomodulatory activity should be an important feature in the search for antileishmanial agents, which would give advantages by enhancing the activity and/or activate the production of soluble mediators such as cytokines and chemokines. These mediators, in the context of the disease, could be associated with protection (Ji et al., 2003).

\section{PHENOLIC COMPOUNDS WITH LEISHMANICIDAL AND IMMUNOMODULATORY ACTIVITIES}

Several reports have raised the antileishmanial effects by phenolics could be exerted through immunomodulatory mechanisms. Proanthocyanidins, such as catechin- $(4 a, 8)$-catechin 1 and fisetinidol-(4 
a,6)-catechin 2, obtained from Khaya senegalensis were evaluated for their leishmanicidal potential on intracellular parasites of Leishmania spp. Although they showed no activity on promastigotes of $L$. donovani, L. major, L. infantum and L. enriettii, these compounds were active against intracellular amastigotes of $L$. donovani with $\mathrm{EC}_{50}$ ca. $3.9 \mu \mathrm{g} / \mathrm{mL}\left(\mathrm{EC}_{50}\right.$ of reference drug, Pentostam ${ }^{\circledR}$, was $7.8 \mu \mathrm{g} / \mathrm{mL}$ ) (Kayser and Abreu, 2001). These results open the possibility to speculate that compounds: 1) could act selectively against amastigotes, 2) could be modified within the host cell and the resulted compound has the antileishmanial activity, or 3) could activate the microbicidal machinery of the host cell. Considering the latter fact, it was evaluated the tumor necrosis factor (TNF) production after exposure to test compounds. Interestingly, both compounds were associated with a TNF production very similar to that shown by the positive control (LPS + IFN-y ), supporting the second hypothesis on immunomodulatory activity-mediated antileishmanial effect. These experiments have been extended to other structurally-related compounds. Within the study performed by Kolodziej et al., 2001, twenty-seven phenolics (some hydrolyzable tannins and related compounds such as ellagitannins, gallotannins, C-glucosidic ellagitannins, and dehydroellagitannins) were evaluated for its leishmanicidal potential. None showed activity against promastigotes of
L. donovani once more, but all phenolics were active against intracellular amastigotes. In addition to these results, other studies have recorded the trend of phenolics (Kolodziej and Kiderlen, 2005; Kiderlen et al., 2001) suggesting common action mechanisms.

In 2003, Radtke et al. published the evaluation of several sage phenolics against a panel of Leishmania parasites. They also found that these compounds exhibited parasiticide activity by stimulating the immune response. The immunomodulatory effects were then evaluated on macrophage's functions in macrophagelike RAW 264.7, including variation of levels of TNF, interleukin-6 (IL-6), and interferon (IFN), when cells were infected with parasites. Similarly, tested compounds were considered not active against promastigotes but caffeic acid $\mathbf{3}$, salvianolic acids $K \mathbf{4}$ and $L \mathbf{5}$, and the salvianolic acid I methyl ester $\mathbf{6}$ exhibited noticeable antileishmanial activities against intracellular amastigotes $\left(\mathrm{IC}_{50}\right.$ 3-23 nM vs. 10-11 nM for the reference Pentostam) and they also showed no cytotoxicity on macrophages (Radtke et al., 2003). However, test phenolics activated Leishmania-infected host cells for releasing TNF ranging 22-117 $\mathrm{U} / \mathrm{mL}$ and $\mathrm{IL}-6$ ranging 3-42 U/mL. In contrast, their TNF- or IL-6-inducing potential in experiments with non-infected host cells was negligible. The results supported the promising scenario that plant phenolics could be qualified for this mode of action in parasite control.

On this context, extracts, coumarins and phenols obtained from a plant of Geraniaceae family, Pelargonium sidoides, were evaluated for their effects on nonspecific immune functions using an in vitro model for intracellular infection with s parasites (Kayser et al., 2001). 
<smiles>Oc1cc(O)c2c(c1)O[C@H](c1ccc(O)c(O)c1)[C@H](O)[C@H]2c1c(O)cc(O)c2c1O[C@H](c1ccc(O)c(O)c1)C(O)C2</smiles>

1<smiles>O=C(/C=C/c1ccc(OC(C(=O)O)C(O)c2ccc(O)c(O)c2)c(O)c1)OC(Cc1ccc(O)c(O)c1)C(=O)O</smiles>

4<smiles>Oc1cc(O)c2c(c1)O[C@H](c1ccc(O)c(O)c1)[C@H](O)[C@H]2c1c(O)cc2c(c1O)CC(O)[C@H](c1ccc(O)c(O)c1)O2</smiles><smiles>O=C(O)/C=C/c1ccc(O)c(O)c1</smiles>

3<smiles>COC(=O)/C(=C\c1ccc(O)c(O)c1)Oc1ccc(/C=C/C(=O)OC(Cc2ccc(O)c(O)c2)C(=O)O)cc1O</smiles>

6
On this context, extracts, coumarins and phenols obtained from a plant of Geraniaceae family, Pelargonium sidoides, were evaluated for their effects on nonspecific immune functions using an in vitro model for intracellular infection with Leshmania parasites (Kayser et al., 2001). Again, test substances exhibited no important activity against promastigotes of L. donovani. Nevertheless, extracts, gallic acid $\mathbf{7}$ and methyl gallate 8 considerably diminished the amastigotes viability within host cells. These data also indicated that the action of the tested substances probably work across activation of leishmanicidal macrophage functions. This fact was concluded by the levels of both TNF- $\alpha$ and inorganic nitric oxides
(iNO) in supernatants of substances-treated macrophage cultures. Due to the large amounts of $\mathbf{7}$ and 8 in P. sidoides, these metabolites were identified as the prominent immunomodulatory principles (Kayser et al., 2001). Identical trend was recently found by Cabanillas et al., 2014, on evaluating various phenolic compounds (diarylheptanoids 9 and flavonoids $10)$ isolated from leaves and rhizomes of Renealmia thyrsoidea (Zingiberaceae). Test compounds exhibited activity against $L$. amazonensis axenic amastigotes at different levels but they were also active in the activation of PPARy nuclear receptor in macrophages. PPARy is an excellent regulator of specific surface receptors involved in the recognition and 
internalization of Leishmania parasites, which is wellknown to promote the host response (Galès et al., 2010; Chan et al., 2012).

The immunomodulator behavior was also confirmed by Zhu et al., 2013 through the evaluation of extracts and phenolic compounds obtained from rhizomes of Osmunda japonica, which exhibited divergent immunomodulatory activity under in vitro conditions using the rat peritoneal cells. The extracts stimulated the NO production, and secretion of IFN- $\gamma, T N F-\alpha$ and $\mathrm{IL}-1 \beta$. While minor $\mathrm{NO}$ enhancement was generated by the aldehyde-type phenolics (such as 4-hydroxybenzaldehyde 11 and 3,4-hydroxybenzaldehyde 12), the benzalacetone-type phenolics (such as 4-hydroxybenzalacetone 13 and 3,4-hydroxybenzalacetone 14) inhibited production of immune mediators including cytokines (TNF- $\alpha, I L-1 \beta, I L-6), N O$, and $P G E_{2}$. These findings also indicated the excellent potential of some phenolics on immunomodulatory activity.
The phenolic lignan licarin-A 15 inhibited the growth Leishmania major promastigotes, by inducing DNA fragmentation (Néris et al., 2013). This compound was more active against intracellular amastigotes $\left(\mathrm{IC}_{50}=9.6\right.$ vs $\left.\mathrm{EC}_{50}=4.7 \mu \mathrm{g} / \mathrm{mL}\right)$. The activity against amastigotes was associated with immunomodulatory effects, since licarin-A-treated macrophage cultures exhibited a decrease in the interleukin (IL)-6 and IL-10 production. Other lignan, niranthin 16, isolated from the aerial parts of the plant Phyllanthus amarus, was found to be a potent anti-leishmanial agent by inhibition of the proliferation of Leishmania amastigotes in infected murine macrophages (with no significant cytotoxicity on the host cells) (Chowdhury et al., 2012). The effect of 16 is considered to be conducted through a Th1-type immune response, which causes $\mathrm{NO}$ production. On this context, main lignans and phenolics (occurring in fractions of Myristica fragans) significantly inhibited, in a dose dependent manner, the production of IL-2,<smiles>O=C(O)Cc1cc(C(=O)O)cc(O)c1O</smiles>

$7 \mathrm{R}=\mathrm{H}$ $8 \mathrm{R}=\mathrm{CH}_{3}$

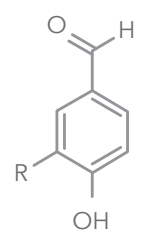

$11 \mathrm{R}=\mathrm{H}$ $12 \mathrm{R}=\mathrm{OH}$<smiles>[R]Oc1ccc(-c2oc3cc(O)cc(O)c3c(=O)c2[R])cc1</smiles>

9<smiles>[R]c1cc(/C=C/C(C)=O)ccc1O</smiles>

$13 \mathrm{R}=\mathrm{H}$ $14 \mathrm{R}=\mathrm{OH}$<smiles>[R]Oc1ccc(CC(=O)/C=C(/C=C/Cc2ccc(O)cc2)C(=O)O)cc1</smiles>

10 
<smiles>O=c1c(O)c(-c2ccc(O)c(O)c2)oc2cc(O)ccc12</smiles>

17<smiles>O=c1c(O)c(-c2ccccc2)oc2ccccc12</smiles>

18<smiles>O=c1cc(-c2ccc(O)c(O)c2)oc2cc(O)cc(O)c12</smiles>

19<smiles>O=c1c(O)c(-c2ccc(O)c(O)c2)oc2cc(O)cc(O)c12</smiles>

20<smiles>COc1c(O)cc2oc(-c3ccc(O)cc3)cc(=O)c2c1O</smiles>

21<smiles>COc1ccc(-c2oc3cc(O)c(OC)c(O)c3c(=O)c2OC)cc1</smiles>

22<smiles>[R]C1C(O)OC(Oc2c(-c3ccc(O)cc3)oc3cc(O)cc(O)c3c2=O)C(O)C(O)C1O</smiles>

23

$\mathrm{R}=$ Galloyl group

IL-4 and IFN-y cytokines in Con A-stimulated lymphocytes (Checker et al., 2008).

Flavonoids have been recognized as active principles against Leishmania amastigotes. Some of them include fisetin 17, 3-hydroxyflavone 18, luteolin 19, quercetin 20 (Tasdemir et al., 2006), hispidulin 21, santin 22 (Sülsen et al., 2007) and flavonoid dimers (Wong et al., 2014). However, their immunomodulatory properties remain unknown. The evaluation of their effects on macrophage immune functions could serve as good information for synergistic antiparasitic compounds with the macrophages as primary effectors (Nahrevanian, 2006). Within this context, Ercil et al., 2005, evaluated 7 flavonoid glicosides (including kaempferol 3-O-(2",3"-di-O-galloyl)- $\beta$ -D-glucopyranoside 23) isolated from Geranium pyrenaicum, against a panel of Leishmania species (L. major, L. donovani and L. amazonensis) on amastigote stage. These compounds also showed appreciable in vitro activities $\left(\mathrm{IC}_{50} 4-27 \mathrm{nM}\right)$ in comparison with Pentostam ( $\left.\mathrm{IC}_{50} 10-11 \mathrm{nM}\right)$. The results provided evidence that flavonoid glycosides are able to stimulate defense mechanisms (through TNF, IFN $\mathrm{Y}$ and IL-6 levels) in Leishmania-infected RAW 264.7 cells.

In conclusion, the published results indicated the good antileishmanial of some phenolics. An important observation through findings regarding test compounds is the selective parasiticide activity against macrophage-internalized amastigote stage, since the action against promastigotes is practically ineffective. This fact is an indicative of the antileishmanial activity by stimulating the host cell immune response. So far, the results therefore show a suggestive value of phenolics as antileishmanial agents. However, the evaluations to estimate its immunomodulatory potential are very scarce and insufficient, so further works are required to address in more detail the promising immunomodulatory effect of phenolics and any other secondary metabolites with remarkable antileishmanial effects. 


\section{ACKNOWLEDGEMENT}

Authors thank Universidad Militar Nueva Granada for the financing support. Product derived by project CIAS-1172 financed by Vicerrectoría de Investigaciones at UMNG - Validity 2013.

\section{REFERENCES}

1. Arevalo I., Ward B., Miller R., Meng T.C., Najar E., Alvarez E., Matlashewski G. and LlanosCuentas A. 2001. Successful treatment of drugresistant cutaneous leishmaniasis in humans by use of imiquimod, an immunomodulator. Clinical Infectious Disease, 33:1847-1851.

2. Assimina Z., Charilaos K. and Fotoula B. 2008. Leishmaniasis: an overlooked public health concern. Health Science Journal, 2:196-205.

3. Aste-Amezaga M., Ma X., Sartori A. and Trinchieri G. 1998. Molecular mechanisms of the induction of IL-12 and its inhibition by IL-10. Journal of Immunology, 160:5936-5944.

4. Cabanillas B.J., Le Lamer A.C., Olagnier D., Castillo D., Arevalo J., Valadeau C., Coste A., Pipy B., Bourdy G., Sauvain M. and Fabre N. 2014. Leishmanicidal compounds and potent PPAR Y activators from Renealmia thyrsoidea (Ruiz \& Pav.) Poepp. \& Endl. Journal of Ethnopharmacology, 57, 18:149-155.

5. Chan M.M., Adapala N. and Chen C. 2012. Peroxisome Proliferator-Activated Receptor- $\boldsymbol{Y}$-mediated polarization of macrophages in Leishmania Infection. PPAR Research, 2012:1-11.

6. Checker R., Chatterjee S., Sharma D., Gupta S., Variyar P., Sharma A. and Poduval T.B. 2008. Immunomodulatory and radioprotective

effects of lignans derived from fresh nutmeg mace (Myristica fragrans) in mammalian splenocytes. International Immunopharmacology, 8:661-669.

7. Chowdhury S., Mukherjee T., Mukhopadhyay R., Mukherjee B., Sengupta S., Chattopadhyay S., Jaisankar P., Roy S. and Majumder H.K. 2012 The lignan niranthin poisons Leishmania donovani topoisomerase IB and favours a Th1 immune response in mice. EMBO Molecular Medicine, 4:1126-1143.

8. Croft SL, Sundar S and Fairlamb AH. 2006. Drug resistance in leishmaniasis. Clinical Microbiology Reviews, 19:111-126.

9. D'Andrea A., Aste-Amezaga M., Valiante N.M., Ma X., Kubin M. and Trinchieri G. 1993. Interleukin 10 (IL-10) inhibits human lymphocyte interferon gamma-production by suppressing natural killer cell stimulatory factor/ IL-12 synthesis in accessory cells. Journal of Experimental Medicine, 178:1041-1048.

10. Ercil D., Kaloga M., Radtke O.A., Sakar M.K., Kiderlen A.F. and Kolodziej H. 2005. O-galloyl flavonoids from Geranium pyrenaicum and their in vitro antileishmanial activity. Turkish Journal of Chemistry, 29:437-443.

11. Faleiro R.J., Kumar R., Hafner L.M. and Engwerda C.R. 2014. Immune regulation during 
Chronic Visceral Leishmaniasis. PLoS Neglected Tropical Diseases, 8:e2914.

12. Galès A., Conduché A., Bernad J., Lefèvre L., Olagnier D., Béraud M., Martin-Blondel G., Linas M.D., Auwerx J., Coste A. and Pipy B. 2010. PPARy controls Dectin-1 expression required for host antifungal defense against Candida albicans. PLoS Pathogens, 6, e1000714.

13. Gómez Romero S.E. 2012. Informe Epidemiológico del Evento Leishmaniasis, Año 2011. Instituto Nacional de Salud: Bogotá.

14. Gutiérrez Dueñas, P. 2010. Comportamiento Epidemiológico de la Leishmaniasis en Colombia. Informe Año 2009 Ajustado. Instituto Nacional de Salud: Bogotá.

15. Gutiérrez Dueñas, P. 2011. Informe Final del Evento de Leishmaniasis, año 2010. Instituto Nacional de Salud: Bogotá.

16. Ji J., Sun J. and Soong L. 2003. Impaired expression of inflammatory cytokines and chemokines at early stages of infection with Leishmania amazonensis. Infection and Immunity, 71:4278-4288.

17. Kassai T. 2006. The impact on database searching arising from inconsistency in the nomenclature of parasitic diseases. Veterinary Parasitology, 138:358-61.
18. Kayser O. and Abreu P.M. 2001. Antileishmania and Immunostimulating Activities of Two Dimeric Proanthocyanidins From Khaya senegalensis. Pharmaceutical Biology, 39:284-288.

19. Kayser O., Kolodziej H. and Kiderlen A.F. 2001. Immunomodulatory principles of Pelargonium sidoides. Phytotherapy Research, 15:122-126.

20. Kiderlen A.F., Kayser O., Ferreira D., Kolodziej H. 2001. Tannins and related compounds: killing of amastigotes of Leishmania donovani and release of nitric oxide and tumour necrosis factor alpha in macrophages in vitro. Zeitschrift für Naturforschung C, 56:444-454.

21. King R.J., Campbell-Lendrum D.H., and Davies C.R. 2004. Predicting geographic variation in cutaneous leishmaniasis, Colombia. Emerging Infectious Disease, 10:598-607.

22. Kolodziej H. and Kiderlen A.F. 2005. Antileishmanial activity and immune modulatory effects of tannins and related compounds on Leishmania parasitised RAW 264.7 cells. Phytochemistry, 66:2056-2071.

23. Kolodziej H., Kayser O., Kiderlen A.F., Ito H., Hatano T., Yoshida T., Foo L.Y. 2001. Antileishmanial activity of hydrolyzable tannins and their modulatory effects on nitric oxide and tumour necrosis factor-alpha 
release in macrophages in vitro. Planta Medica, 67:825-832.

24. Maurer-Cecchini A., Decuypere S., Chappuis F., Alexandrenne C., De Doncker S., Boelaert M., Dujardin J.C., Loutan L., Dayer J.M., TuIliano G., Arevalo J., Llanos-Cuentas A. and Chizzolini C. 2009. Immunological determinants of clinical outcome in Peruvian patients with tegumentary leishmaniasis treated with pentavalent antimonials. Infection and Immunity, 77:2022-2029.

25. Mohapatra S. 2014. Drug resistance in leishmaniasis: Newer developments. Tropical Parasitology, 4:4-9

26. Monzote L. 2009. Current treatment of Leishmaniasis: a review. The Open Antimicrobial Agents Journal, 1, 9-19.

27. Myler P.J. and N. Fasel. 2008. Leishmania: after the genome. Wymondham: Caister Academic. xiv, Pag 306.

28. Nahrevanian H. 2006. Immune effector mechanisms of the nitric oxide pathway in malaria: cytotoxicity versus cytoprotection. Brazilian Journal of Infectious Diseases, 10:283-292.

29. Néris P.L., Caldas J.P., Rodrigues Y.K., Amorim F.M., Leite J.A., Rodrigues-Mascarenhas S., Barbosa-Filho J.M., Rodrigues L.C. and Oliveira M.R. 2013. Neolignan Licarin A presents effect against Leishmania (Leishmania) major associated with immunomodulation in vitro. Experimental Parasitology, 135:307-313.

30. Pan American Health Organization (PAHO), Health in the Americas. 2007. Scientific and technical publication (Washington, D.C.). 2007, Washington, D.C.: Pan American Health Organization, Pan American Sanitary Bureau, Regional Office of the World Health Organization. 2 v.

31. Pérez-Victoria F.J., Sánchez-Cañete M.P., Seifert K., Croft S.L., Sundar S., Castanys S. and Gamarro F. 2006. Mechanisms of experimental resistance of Leishmania to miltefosine: Implications for clinical use. Drug Resistance Updates, 9:26-39.

32. Radtke O.A., Foo L.Y., Lu Y., Kiderlen A.F. and Kolodziej H. 2003. Evaluation of sage phenolics for their antileishmanial activity and modulatory effects on interleukin-6, interferon and tumour necrosis factor-alpha-release in RAW 264.7 cells. Zeitschrift für Naturforschung C. 58:395-400.

33. Reithinger R and Coleman P.G. 2007. Treating cutaneous leishmaniasis patients in Kabul, Afghanistan: cost-effectiveness of an operational program in a complex emergency setting. BMC Infectious Diseases, 7:3. 
34. Ribeiro-Gomes F.L., Otero A.C., Gomes N.A., Moniz-De-Souza M.C., Cysne-Finkelstein L., Arnholdt A.C., Calich V.L., Coutinho S.G., Lopes M.F. and DosReis G.A. 2009. Macrophage interactions with neutrophils regulate Leishmania major infection. Journal of Immunology, 172:4454-4462.

35. Robledo S.M., Puerta J.A., Muñoz D.L., Guardo M. and Vélez I.D. 2006. Efficacy and tolerance of pentamidine for treatment of cutaneous leishmaniasis caused by por L. (V) panamensis in Colombia. Biomedica, 26 Suppl 1:188-93.

36. Rodrigues M.L.O., Costa R.S., Souza C.S., Foss N.T. and Roselino A.M.F. 1999. Nephrotoxicity attributed to meglumine antimoniate (Glucantime) in the treatment of generalized cutaneous leishmaniasis. Revista do Instituto de Medicina Tropical de São Paulo, 41:33-37.

37. Rodríguez-Barraquer I., Góngora R., Prager M., Pacheco R., Montero L.M., Navas A., Ferro C., Miranda M.C. and Saravia N.G. 2008. Etiologic agent of an epidemic of cutaneous leishmaniasis in Tolima, Colombia. American Journal of Tropical Medicine and Hygiene, 78:276-82.

38. Rojas R., Valderrama L., Valderrama M., Varona M.X., Ouellette M. and Saravia N.G. 2006. Resistance to antimony and treatment failure in human Leishmania (Viannia) infection. Journal of Infectious Disease, 193:1375-1383.

39. Saravia N.G., Segura I., Holguin A.F., Santrich C., Valderrama L. and Ocampo C. 1998. Epidemiologic, genetic, and clinical associations among phenotypically distinct populations of Leishmania (Viannia) in Colombia. American Journal of Tropical Medicine and Hygiene, 59: 86-94.

40. Saravia N.G., Weigle K., Navas C., Segura I., Valderrama L., Valencia A.Z., Escorcia B. and McMahon-Pratt D. 2002. Heterogeneity, geographic distribution, and pathogenicity of serodemes of Leishmania viannia in Colombia. American Journal of Tropical Medicine and Hygiene, 66:738-44.

41. Sharma U. and Singh S. 2009. Immunobiology of leishmaniasis. Indian Journal of Experimental Biology. 47:412-423.

42. Singh O.P. and Sundar S. 2014. Immunotherapy and targeted therapies in treatment of visceral leishmaniasis: current status and future prospects. Frontiers in Immunology, 5:296, 1-9.

43. Sülsen V.P., Cazorla S.I., Frank F.M., Redko F.C., Anesini C.A., Coussio J.D., Malchiodi E.L., Martino V.S. and Muschietti L.V. 2007. Trypanocidal and leishmanicidal activities of flavonoids from Argentine medicinal plants. 
American Journal of Tropical Medicine and Hygiene, 77:654-659.

44. Sundar S., Rosenkaimer F., Lesser M.L. and Murray H.W. 1995. Immunochemotherapy for a systemic intracellular infection: accelerated response using interferon-gamma in visceral leishmaniasis. Journal of Infectious Disease, 171:992-996.

45. Tasdemir D., Kaiser M., Brun R., Yardley V., Schmidt T.J., Tosun F. and Rüedi P. 2006. Antitrypanosomal and antileishmanial activities of flavonoids and their analogues: in vitro, in vivo, structure-activity relationship, and quantitative structure-activity relationship studies. Antimicrobial Agents and Chemotherapy, 50:1352-1364.

46. Velez I.D. 1995. ¿Leishmaniosis o Leishmaniasis?. latreia, 8:124-126.

47. Wong I.L., Chan K.F., Chen Y.F., Lun Z.R., Chan T.H. and Chow L.M. 2014. In vitro and in vivo efficacy of novel flavonoid dimers against cutaneous leishmaniasis. Antimicrobial Agents and Chemotherapy, 58:3379-3388.

48. World Health Organization (WHO). Executive Board. Session, Control of leishmaniasis : report by the Secretariat. 2006, Geneva: World Health Organization. Pag 7.
49. World Health Organization (WHO). Leishmaniasis: the global trend. Neglected tropical diseases 2009 30-01-2009 10-03-2010]; Available from: http://www.who.int/neglected_ diseases/integrated_media_leishmaniasis/ en/index.html.

50. Zhu X.X., Li Y.J., Yang L., Zhang D., Chen Y., Kmonickova E., Weng X.G., Yang Q. and Zídek Z. 2013. Divergent immunomodulatory effects of extracts and phenolic compounds from the fern Osmunda japonica Thunb. Chinese Journal of Integrative Medicine, 19:761-770. 